\title{
Karyological Studies of Sixteen Cultivars of Tepary Bean (Phaseolus acutifolius A. Gray)
}

\author{
M. Munian and D. Subramanian \\ Department of Botany, Annamalai University, \\ Annamalainagar, 608002, India
}

Acceped May 25, 1983

The cultivated species of Phaseolus acutifolius A. Gray has a wide range of cultivars with distinct and diffused geographical adaptability. Although the cultivars of this species are known to be diploids $(2 n=22)$ the detail karyotypic studies on a large number of cultivars have not been made so far to establish the standardised karyotype for this species. The cultivars taken up in the investigation are known to have wide differences in their morphology and behaviour. In view of this, a detailed analysis of the somatic chromosomes is considered necessary.

\section{Material and method}

Karyotype of sixteen cultivars of Tepary bean was studied from the root tips obtained by germinating the seeds in l'clay pots filled up with garden soil, leaf mold and fine sand in a suitable proportion. Fresh root tips were collected at $9.30 \mathrm{a} . \mathrm{m}$. The root tips were pretreated in $0.002 \%$ hydroxyquinoline kept at $4^{\circ} \mathrm{C}$ for 3 hours. After a thorough wash the root tips were then fixed in $1: 3$ acetic alcohol for 3 hours. Following iron alum haematoxylin squash technique (Mariumthu and Subramaniam 1960) root tip squashes were made and the slides sealed.

Six camera lucida drawings were taken for each cultivar, using $12.5 \mathrm{x}$ ocular and oil immersion objective $100 \mathrm{x}$ from the temporary preparations. Somatic counts and karyotypic formulae were worked out for all the 16 cultivars. The position of the centromeres was determined from a comparative study of several metaphase plates. The chromosomes are assigned to different types basing on their relative length, position of centromere and presence or absence of secondary constriction.

The abbreviations used for the purpose are $\mathbf{M}=$ median, $\mathrm{Sm}=$ submedian, $\mathrm{St}=$ subterminal, $\mathrm{Smst}=$ secondarily constricted chromosome with submedian primary constriction. Chromosome types include also the following: $\mathrm{A}=$ above $3.0 \mu \mathrm{m}$ to $4.0 \mu \mathrm{m}, \mathrm{B}=$ above $2.0 \mu \mathrm{m}$ to $3.0 \mu \mathrm{m}, \mathrm{C}=$ above $1.0 \mu \mathrm{m}$ to $2.0 \mu \mathrm{m}, \mathrm{D}=$ upto $1.0 \mu \mathrm{m}$. The figures in the karyotype formula pertain to the number of pairs of chromosomes. TF\% was calculated by the formula given by Huziwara (1962).

An average karyotype was worked out basing in the results of chromosome morphology obtained for all the 16 cultivars. 


\section{Results}

The cytological study in Tepary bean showed better division from 9 a.m. to 10 a.m. at any season.

The chromosome number for all the 16 cultivars was found to be $2 n=22$ (Plate

Table 1. Details of karyotype of sixteen cultivars of Phaseolus acutifolius A. Gray

\begin{tabular}{|c|c|c|c|c|c|c|c|c|c|}
\hline \multirow[b]{2}{*}{$\begin{array}{l}\text { S. } \\
\text { no. }\end{array}$} & \multirow[b]{2}{*}{$\begin{array}{l}\text { Name of } \\
\text { cultivars }\end{array}$} & \multirow[b]{2}{*}{$2 n$} & \multicolumn{4}{|c|}{ Type of chromosome } & \multirow[b]{2}{*}{$\begin{array}{l}\text { Total } \\
\text { chromo- } \\
\text { some } \\
\text { length } \\
(\mu \mathrm{m})\end{array}$} & \multirow[b]{2}{*}{$\begin{array}{l}\text { Range in } \\
\text { chromo- } \\
\text { some } \\
\text { length } \\
(\mu \mathrm{m})\end{array}$} & \multirow[b]{2}{*}{$\mathrm{TF} \%$} \\
\hline & & & Median & $\begin{array}{l}\text { Sub- } \\
\text { median }\end{array}$ & $\begin{array}{l}\text { Sub- } \\
\text { terminal }\end{array}$ & $\begin{array}{l}\text { Submedian } \\
\text { with } \\
\text { secondary } \\
\text { con- } \\
\text { striction }\end{array}$ & & & \\
\hline 1 & $\begin{array}{l}\text { P.I. No. } 197041 \\
\text { EC. No. } 131740\end{array}$ & 22 & 6 & 4 & 1 & - & 40.0 & $1.4-2.2$ & 34.50 \\
\hline 2 & $\begin{array}{l}\text { P.I. No. } 200902 \\
\text { EC. No. } 131741\end{array}$ & 22 & 7 & 4 & - & - & 42.8 & $1.6-2.2$ & 38.79 \\
\hline 3 & $\begin{array}{l}\text { P.I. No. } 201268 \\
\text { EC. No. } 131742\end{array}$ & 22 & 7 & 4 & 一 & 一 & 52.4 & $2.0-3.0$ & 38.55 \\
\hline 4 & $\begin{array}{l}\text { P.I. No. } 263590 \\
\text { EC. No. } 131743\end{array}$ & 22 & 6 & 4 & 1 & - & 47.2 & $1.4-2.6$ & 36.02 \\
\hline 5 & $\begin{array}{l}\text { P.I. No. } 286303 \\
\text { EC. No. } 131745\end{array}$ & 22 & 7 & 4 & - & - & 27.2 & $0.8-1.5$ & 37.50 \\
\hline 6 & $\begin{array}{l}\text { P.I. No. } 310606 \\
\text { EC. No. } 131746\end{array}$ & 22 & 6 & 5 & - & - & 53.6 & $1.8-3.4$ & 37.69 \\
\hline 7 & $\begin{array}{l}\text { P.I. No. } 318001 \\
\text { EC. No. } 131748\end{array}$ & 22 & 6 & 5 & - & - & 38.0 & $1.4-2.2$ & 35.79 \\
\hline 8 & $\begin{array}{l}\text { P.I. No. } 310803 \\
\text { EC. No. } 131750\end{array}$ & 22 & 4 & 3 & 4 & - & 44.0 & $1.6-2.0$ & 30.45 \\
\hline 9 & $\begin{array}{l}\text { P.I. No. } 312133 \\
\text { EC. No. } 131751\end{array}$ & 22 & 6 & 3 & 1 & 1 & 41.6 & $1.4-3.2$ & 35.58 \\
\hline 10 & $\begin{array}{l}\text { P.I. No. } 319438 \\
\text { EC. No. } 131753\end{array}$ & 22 & 5 & 3 & 3 & - & 40.4 & $1.4-2.2$ & 32.67 \\
\hline 11 & $\begin{array}{l}\text { P.I. No. } 319442 \\
\text { EC. No. } 131755\end{array}$ & 22 & 5 & 4 & 2 & - & 33.2 & $1.0-2.0$ & 33.74 \\
\hline 12 & $\begin{array}{l}\text { P.I. No. } 319444 \\
\text { EC. No. } 131757\end{array}$ & 22 & 6 & 4 & 1 & - & 45.2 & $1.6-2.4$ & 35.84 \\
\hline 13 & $\begin{array}{l}\text { P.I. No. } 319447 \\
\text { EC. No. } 131759\end{array}$ & 22 & 7 & 4 & - & - & 41.6 & $1.6-2.2$ & 38.46 \\
\hline 14 & $\begin{array}{l}\text { P.I. No. } 331181 \\
\text { EC. No. } 131760\end{array}$ & 22 & 5 & 4 & 2 & - & 32.2 & $1.2-2.0$ & 32.31 \\
\hline 15 & $\begin{array}{l}\text { Nebraska } \\
\text { cultivar }\end{array}$ & 22 & 3 & 3 & 1 & 4 & 56.8 & $2.0-3.2$ & 32.39 \\
\hline 16 & var. latifolius & 22 & 5 & 2 & 3 & 1 & 39.2 & $1.2-3.0$ & 33.16 \\
\hline
\end{tabular}

1, Figs. 1 to 18). All the cultivars possess smaller chromosomes. Out of the total of 11 pairs there are 3 pairs of secondary constricted chromosomes in only one cultivar from Nebraska and only one pair of such chromosomes in two cultivars (var. latifolius and P.I. No. 312133). In all other cultivars, secondary constricted chromosomes were absent. Based on the analysis of chromosome morphology, the de- 
tails of karyotype of all the cultivars are given in Table 1. The idiogram of somatic karyotypes for all the cultivars and also the idiogram of an average karyotype are here (Plate 2, Figs. 1 to 17)
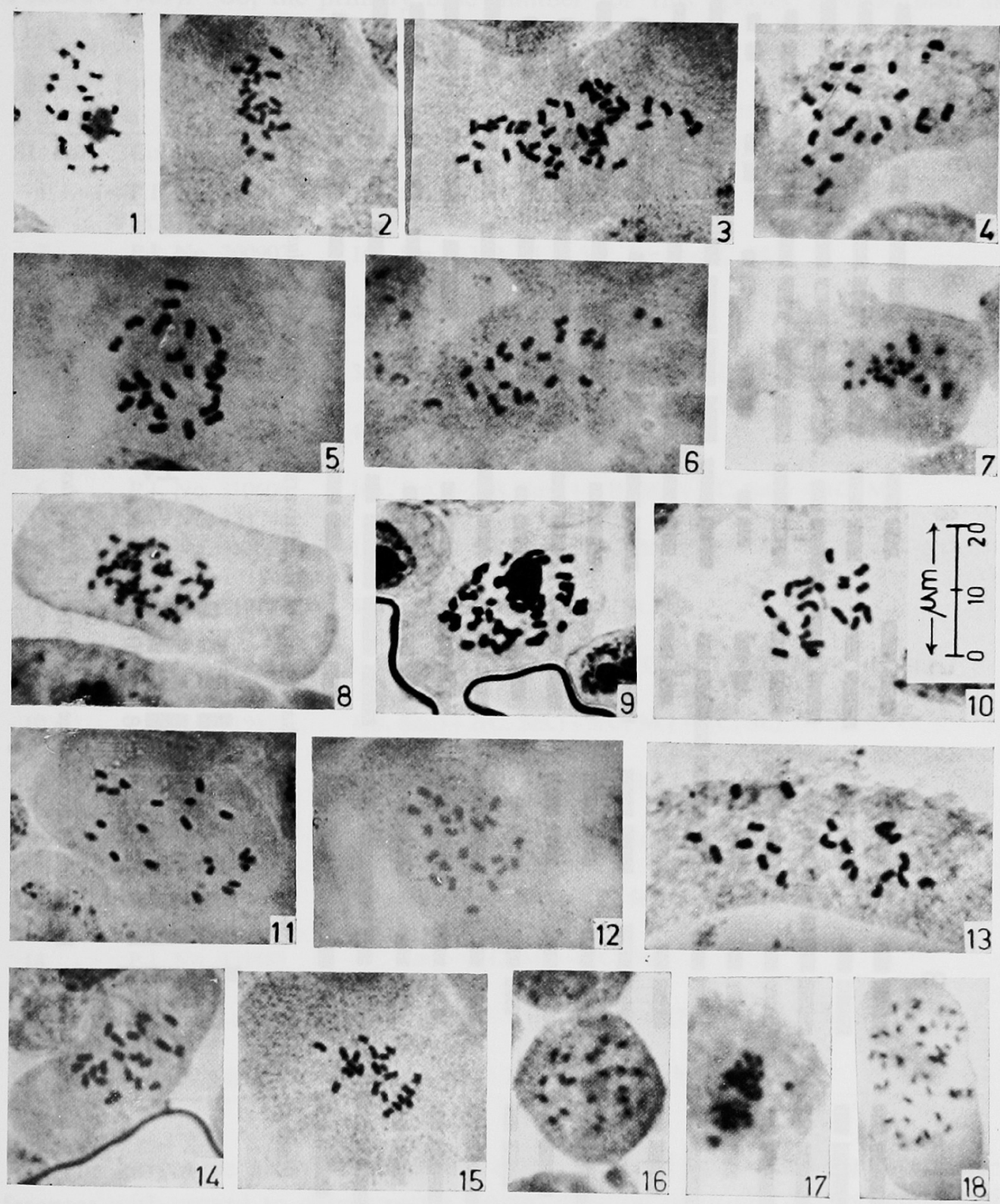

Plate 1: Figs. 1-18. Plate of cultivars of Phaseolus acutifolius. 1 and 9, somatic prometaphase plate of cultivars P.I. No. 197041 and P.I. No. 310606. 2-8, 10-16 and 18, somatic metaphas plates of cultivars: P.I. No. 197041, No. 200902, No. 201268, No. 263590, No. 286303, No. 310606, No. 310606 , No. 310801 , No. 310803 , No. 312133 , No. 319438 , No. 319442 , No. 331181 and No. 331181. 17, P.I. No. 331181 shows precocious movement. 


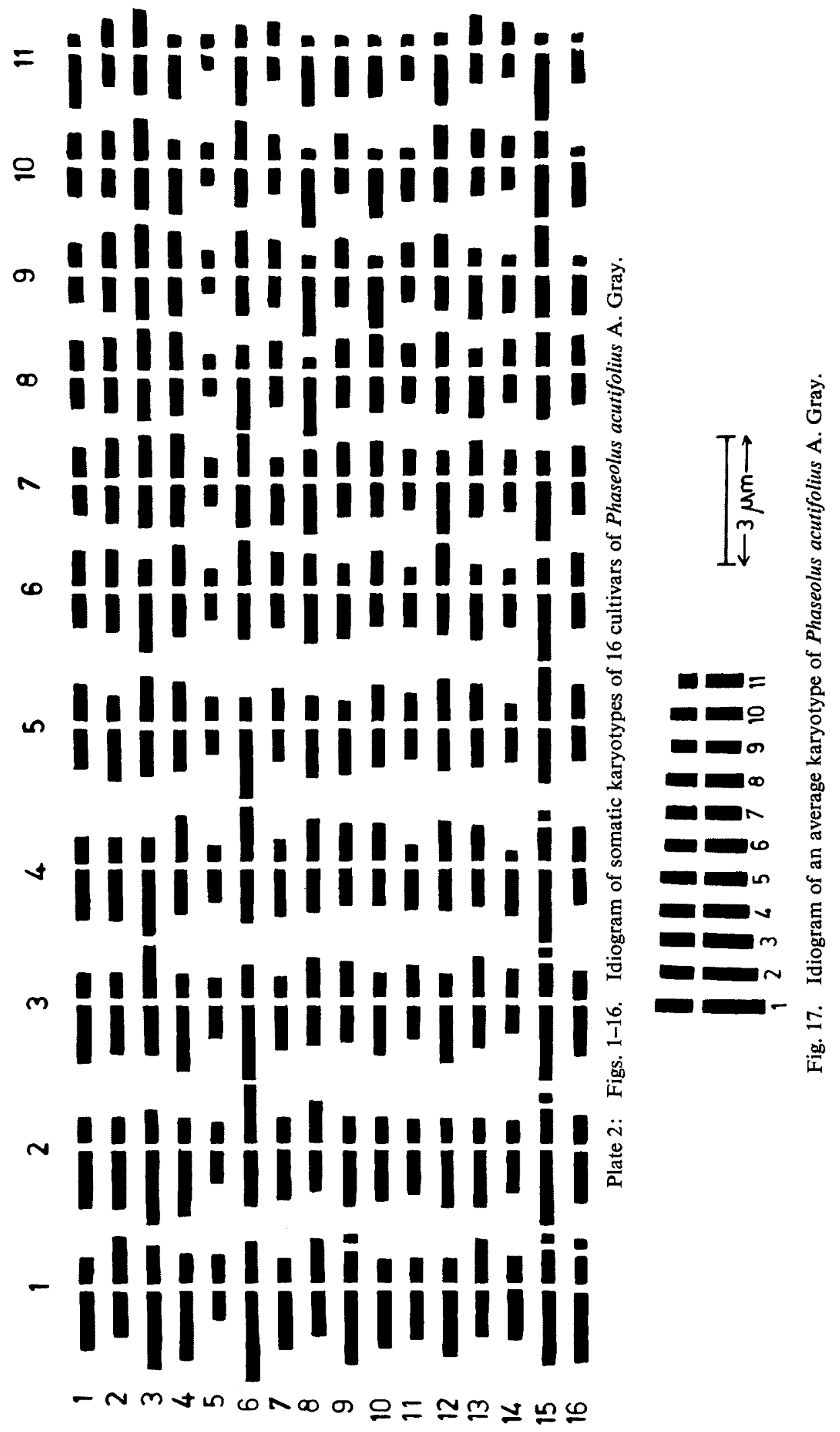




\section{Discussion}

All the 16 cultivars of Phaseolus acutifolius A. Gray are found to have $2 \mathrm{n}=22$. This agrees with the reports of Karpechenko 1925b and Shibata 1962a (vide Fedorov 1969). So, the primary base number for this species is confirmed as 11.

Table 2. Karyotype formula of sixteen cultivars

\begin{tabular}{|c|c|c|}
\hline S1. no. & Cultivar name & Karyotype formula \\
\hline 1 & $\begin{array}{l}\text { P.I. No. } 197041 \\
\text { EC. No. } 131740\end{array}$ & 3 (B. Sm. $)+1($ C. Sm. $)+6($ C. M. $)+1$ (C. St. $)$ \\
\hline 2 & $\begin{array}{l}\text { P.I. No. } 200902 \\
\text { EC. No. } 131741\end{array}$ & $1($ B. Sm. $)+1($ B. M. $)+3($ C. Sm. $)+6($ C. M. $)$ \\
\hline 3 & $\begin{array}{l}\text { P.I. No. } 201268 \\
\text { EC. No. } 131742\end{array}$ & $4($ B. $\mathrm{Sm})+.6($ B. M. $)+1$ (C. M. $)$ \\
\hline 4 & $\begin{array}{l}\text { P.I. No. } 263590 \\
\text { EC. No. } 131743\end{array}$ & 3 (B. Sm). +4 (B. M. $)+1$ (C. Sm. $)+2($ C. M. $)+1$ (C. St.) \\
\hline 5 & $\begin{array}{l}\text { P.I. No. } 286303 \\
\text { EC. No. } 131745\end{array}$ & 4 (C. Sm.) +3 (C. M.) +4 (D. M.) \\
\hline 6 & $\begin{array}{l}\text { P.I. No. } 310606 \\
\text { EC. No. } 131746\end{array}$ & $1($ A. Sm. $)+2$ (B. Sm. $)+4($ B. M. $)+2$ (C. Sm. $)+2$ (C. M.) \\
\hline 7 & $\begin{array}{l}\text { P.I. No. } 310801 \\
\text { EC. No. } 131748\end{array}$ & $1($ B. Sm. $)+4($ C. Sm. $)+6($ C. M. $)$ \\
\hline 8 & $\begin{array}{l}\text { P.I. No. } 310803 \\
\text { EC. No. } 131750\end{array}$ & 4 (B. M.) +3 (C. Sm.) +4 (S. St.) \\
\hline 9 & $\begin{array}{l}\text { P.I. No. } 312133 \\
\text { EC. No. } 131751\end{array}$ & 1 (A. Sm. St. $)+1$ (B. Sm. $)+2($ C. Sm. $)+6($ C. M. $)+1$ (C. St. $)$ \\
\hline 10 & $\begin{array}{l}\text { P.I. No. } 319438 \\
\text { EC. No. } 131753\end{array}$ & $1($ B. Sm. $)+2$ (C. Sm. $)+5($ C. M. $)+3($ C. St. $)$ \\
\hline 11 & $\begin{array}{l}\text { P.I. No. } 319442 \\
\text { EC. No. } 131755\end{array}$ & $4($ C. Sm. $)+5$ (C. M. $)+1$ (C. St. $)+1(D$, St. $)$ \\
\hline 12 & $\begin{array}{l}\text { P.I. No. } 319444 \\
\text { EC. No. } 131757\end{array}$ & $3($ B. Sm. $)+3($ B. M. $)+1($ C. Sm. $)+3($ C. M. $)+1($ C. St. $)$ \\
\hline 13 & $\begin{array}{l}\text { P.I. No. } 319447 \\
\text { EC. No. } 131759\end{array}$ & $1($ B. Sm. $)+2($ B. M. $)+3($ C. Sm. $)+5$ (C. M. $)$ \\
\hline 14 & $\begin{array}{l}\text { P.I. No. } 331181 \\
\text { EC. No. } 131760\end{array}$ & 4 (C. Sm.) +5 (C. M.) +2 (C. St.) \\
\hline 15 & $\begin{array}{l}\text { Nebraska cultivar } \\
\text { var. latifolius }\end{array}$ & $\begin{array}{l}\text { 3(A. Sm. St. })+1 \text { (B. Sm. St. })+2(\text { B. Sm. })+3(\text { B. M. })+1(\text { C. Sm. }) \\
\quad+1 \text { (C. St. }) \\
1 \text { (B. Sm. St. })+2 \text { (C. Sm. })+5 \text { (C. M. })+3(\text { C. St. })\end{array}$ \\
\hline
\end{tabular}

The karyotype analyses of all the cultivars reveal reasonably significant differences with regard to chromosome length, position of primary constriction and TF $\% .56 .8 \mu \mathrm{m}$ is the maximum total chromosome length and the minimum is $27.2 \mu \mathrm{m}$. A large number of cultivars (10 numbers) have been noted within a range

Plate. 2. Figs. 1-16. Idiogram of somatic Karyotypes of 16 cultivars of Phaseolus acutifolius. 1. P.I. No. 197041 , 2. No. 200902 , 3. No. 201268 , 4. No. 263590 , 5. No. 286303 , 6. No. 310606 , 7. No. 310801, 8. No. 310803, 9. No. 312233, 10. No. 319438, 11. No. 319442, 12, No. 319444, 13.

No. 319447,14 . No. 331181,15 . Nebraska cultivar and 16. var. latifolius. 
of total chromosome length of $38.0 \mu \mathrm{m}$ to $47.2 \mu \mathrm{m}$. The study of the range in chromosome length reveals that the cultivar with P.I. No. 286303 has the shortest $(0.8 \mu \mathrm{m})$ and the cultivar with P.I. No. 310660 has the longest chromosomes (3.4 $\mu \mathrm{m})$ in their somatic cells as compared with other cultivars.

The striking similarities in the karyomorphology of 13 out of 16 cultivars are in their first chromosomes which are not secondary constricted and the rest of the chromosomes are found either with median or submedian or subterminal primary constrictions. An average karyotype (Plate. 2, Fig. 17) drawn by utilizing arithmetic mean of the individual chromosome of the whole somatic complement for all the varieties, however, reveals a different picture. Datta (1975) on sweet pea and Goswami (1979) on black gram, have utilized the mean values and found similar features.

The TF $\%$ for 10 cultivars is found to be in a close range of 34.50 to 38.79 and the cultivars under this range have more or less symmetrical karyotypes. Here, the median constricted chromosomes are more in number than the chromosomes with submedian and subterminal constrictions. The other 6 cultivars have shown comparatively an asymmetrical karyotypes with TF\% ranging from 30.45 to 33.74 . Here there are more number of submedian and subterminal constricted chromosomes when compared to the median constricted chromosomses. The karyotypes in general for different species of Phaseolus have been reported as symmetrical (Sen and Chheda 1958, Krishnan and De 1965, De and Krishnan 1966, Singh and Roy 1970).

The presence of secondary constriction only in one pair of chromosomes of only two cultivars and median primary constriction in a large number of chromosomes of a somatic complement for almost all the cultivars apparently suggested the ancient origin of these cultivars. Anyhow, the presence of 4 pairs of secondary constricted chromosomes coupled with the presence of submedian primary constriction in a large number of chromosomes of the somatic complement in Nebraska cultivar showed the recent origin. Goswami (1979) has stated the recent origin of the varieties of Black gram by studying the karyotypes of thirty two varieties. In absence of any evidence of chromosome aberrations in meiosis which is regular, it is difficult to ascertain the exact mechanism of origin of these karyotypic differences. In any case, these changes may have helped the process of evolution and the emergence of different varieties. On the other hand, the uniformity in the base number and considerable similarity in gross nature of the karyotypes suggest that gene mutation was the principal factor in evolution.

\section{Summary}

Karyotypic analysis of sixteen cultivars of Phaseolus acutifolius A. Gray showed reasonable differences between the cultivars on chromosome length, position of primary constriction and in TF\%. Only in two cultivars, a pair of chromosomes was secondarily constricted and most of the chomosomes in all the cultivars, excepting the Nebraska cultivar, possess mostly medianly constricted chromosomes. In 
Nebraska cultivar, there are 4 pairs of secondary constricted chromosomes and most of the chromosomes possess submedian primary constrictions. An average karyotype of Phaseolus acutifolius has been suggested basing in the results included herewith.

The observation of $\mathrm{TF} \%$ ranging from 34.50 to 38.79 revealed a symmetrical karyotypes for 10 cultivars. The others 6 cultivars were observed to be asymmetrical with TF ranging from 30.45 to 33.74 . The importance of karyotypic differences in evolution of varieties within a species has been discussed.

\section{Acknowledgment}

We are very pleased to express our heartfelt thanks to Dr. Dermot P. Coyne, Professor and Head of the Department of Horticulture and Forestry, University of Nebraska, Lincoln and Dr. Howard L. Hyland, Plant Introduction Station, United States Department of Agriculture, Beltsville, Maryland, U.S.A., for their valuable and kind supply of fresh seeds of different cultivars and varieties of Phaseolus acutifolius.

\section{References}

Datta, P. D. 1975. Natural variation of chromosome length and a critical assessment of the karyotype in sweet pea. Cytologia 40: 561-568.

De, D. N. and Krishan, R. 1966. Studies on pachytene and somatic chromosome of Phaseolus mungol L. Genetica 37: 581-587.

Fedorov, A. N. A. 1969 . Chromosome Atlas of Flowering Plants. Acad. Sci. of the U.S.S.R.

Goswami, L. C. 1979. Karyological studies of thirty two varieties of Black gram (Phaseolus mungo L.). Cytologia 44: 549-556.

Huziwara, Y. 1956 Karyotype analysis in some genera of Compositae. 1. Karyotype of Japanese Eupatorium. Cytologia 21: 114-123.

Karpechenko, C. D. 1925. On the chromosomes of Phaseolineae. Bull. Appl. Bot. Genet. and Pl. Breed. 14: 271-279.

Krishnan, R. and De, D. N. 1965. Studies on pachytene and somatic chromosomes of Phaseolus aureus Roxb. Nucleus 8: 7-16.

Marimuthu, K. M. and Subramaniam, M. K. 1960. A haematoxylin squash method for the root tips of Dolichos lablab L. Curr. Sci. 29 : 482-483.

Rao, M. A. 1929. Cytology of some crop plants of South Inida. J. Indian. Bot. Soc. 8: 126.

Sen, N. K. and Chheda, H. R. 1958. Colchicine induced tetraploids of five varieties of black gram. Ind. J. Genet. and Pt. Br. $18: 238-248$.

Shibata, K. 1962a. Cytological studies on some wild and cultivated plants of Columbia. J. Agric. Sci. Tokyo Nogyo Daigaku 8: 49-62.

Singh, A. and Roy, R. P. 1970. Karyological studies in Trigonella, Indigofera and Phaseolus. Nucleus $13: 41-54$. 